\title{
A Simple EXPORT Country-Market ScreEning TECHNIQUE FOR SMALL US BUSINESSES: A Packaged Good Illustration
}

\author{
Jose F. Medina \\ Joel Saegert \\ John Merrifield \\ University of Texas at San Antonio \\ San Antonio, TX
}

\begin{abstract}
US small businesses are in need of processes and techniques that help them alleviate the difficult experience of choosing foreign markets. Using a generic screening process, this paper explains the stages, the screening criteria, and the ranking techniques for selecting country-markets. The paper illustrates the application of Shift-Share Analysis (SSA) as a simple technique to rank country-market potentials. Results from an analysis of a packaged good show that SSA is an adequate ranking technique to identify preliminary country prospects. Implications for small businesses and future research are given.
\end{abstract}

\section{Introduction}

Efforts to export to other countries usually encounter barriers less frequently faced in the domestic marketplace, such as differences in cultural, legal, political, and economic environments. At the same time, many of the sales barriers encountered in export marketing are similar to those of domestic marketing, e.g., ineffectiveness of dealers and distributors, changing customer preferences, lack of customer knowledge of the product, etc. Despite the level of similarity (or dissimilarity) of the barriers between domestic and export marketing, small US businesses in growing numbers are eager to step into the international business arena. Reports from the government (Prosak, 1993) and the general business media (BusinessWeek. 1995) indicate that small US firms, with reasonably priced consumer products and with a proven record of acceptability in the domestic market, have strong export potential.

Although assessing a product's export potential is a critical step in export marketing, determining where that potential is the greatest is just as important. Which countries to export to first and how many is always a vexing question that has challenged many small and medium-sized exporters (McNiven, 
1991; Ramaswami \& Yang, 1990). Research has found that perceived trade barriers are traced back to managers' difficulties in locating foreign markets (Alexandrides, 1971; Tesar \& Tarleton, 1982). Unfortunately, there is not a simple, appropriate, and reliable technique to help identify attractive world markets. This is a troublesome circumstance for the many small businesses with simple decision structures (Miller \& Friesen, 1980).

The export marketing literature is sparse at best in evaluating processes and techniques on how to select country markets. Existing treatments vary from the sophisticated, such as comparative cluster analysis (Sheti, 1971), to the much simpler, such as multiple factor analysis (Samli, 1977) and shift-share analysis (Green \& Allaway, 1985). One problem with the more sophisticated techniques is that they require large amounts of data manipulation to screen candidate countries. Another limitation is that these approaches require good knowledge and understanding of complex statistical techniques. On the other hand, a simpler and more parsimonious technique such as shift-share analysis (SSA) appears to possess characteristics for wider application.

Shift-share analysis has been around in the economic literature for a long time (Fuchs, 1959). It has been traditionally used in studies of regional economics to assess the differences between regional and national trends of economic phenomena (Merrifield, 1983). It has been successfully applied in measuring market growth by eliminating many of the limitations inherent in the use of absolute and relative measures (Huff \& Sherr, 1967). Some studies have extended its use to international trade, for example, to determine the composition of trade flows for the US and its trading partners (Green, 1985; Green \& Allaway, 1985; Green \& Larsen, 1991a; Green \& Larsen, 1991b). To be sure, SSA has three important limitations regarding its use in international trade. First, it involves only two points in time; choosing different points in time might render different ranking results. Second, it only ranks one product category at a time. And, finally, the technique's predictive validity has not been tested for ranking exports markets.

One result of applying SSA to an export screening process would be that it produces a smaller set of export country-markets that would warrant a more in-depth and focused investigation. In addition, the greater accessibility to export statistics through the Internet and similar media renders SSA a more valuable and useful research technique to be applied by small businesses. The purpose of this paper is to examine the effectiveness of applying the SSA ranking technique to readily available US export statistics to measure country-market market potentials. The literature is briefly reviewed regarding the importance to small businesses of exporting as a competitive country-market entry strategy; generic methods for the export country-market screening process; and the convenience and availability of trade data and the shift-share analysis technique. A methodology for a simple export country-market screening method is described using the SSA ranking technique, following which results are described and tested against independent sources for convergent 
validity. This version of SSA is intended to be one that can be easily understood and used by small US export businesses. Thus, the last two sections discuss implications for such companies and make recommendations for research.

\section{Exporting As a Competitive Country-Market Entry Strategy}

Exporting should be seen as only one of several possible country-market competitive entry strategies - e.g., licensing, joint ventures, collaborative alliances, and direct investment (Agarwal \& Ramaswami, 1992; Cavusgil \& Zou, 1994). An entry strategy is a comprehensive plan that sets forth the objectives, goals, resources, and policies that will guide a company's international business operation. Specifically, country-market entry strategies require decisions about the choice of a target country and the choice of an entry mode to penetrate that target (Root, 1987). Additionally, a competitive strategy requires decisions concerning the level of expansion - concentration versus diversification - and competitive posture - defensive versus offensive (Ayal \& Zif, 1978). A strategy of country-market concentration would focus available resources among a small number of country-markets. Conversely, diversification allocates limited resources over a larger number of country-markets. Small firms stepping into the international arena would benefit from a concentration approach, where high market growth rate and sales stability allow firms to gradually capture a few "neutral markets."

Experience has demonstrated that many small US companies become committed to international markets only when they no longer believe that they can attain their strategic objectives by remaining at home (Root, 1987). Because of their limited international experience and resources, and a "typically" defensive stance relative to their larger competitors, small firms tend to opt for foreign markets that have similar demand structures as those in the US (Davidson, 1983). Consequently, Ayal \& Zif (1978) would argue that small firms should launch concentrated efforts to capture a few "neutral" countrymarkets to expand their domestic base, and thus defend themselves from a larger competitor's attack at home. Many small companies in the United States seem to have now reached the point at which they need to actively seek export opportunities (BusinessWeek, 1995).

Conventional wisdom and recent empirical research suggest that most small US businesses do not have the capabilities to undertake any entry strategy planning beyond exports (Baird, Lyles \& Orris, 1993; Baird, Lyles \& Orris, 1994), partly because of their unpreparedness to deal with foreign business practices and foreign government regulations (Czinkota, 1994). At the same time, many potential foreign markets do not seem to offer a large enough opportunity to justify more elaborate entry strategies beyond exports. Thus, exporting may be seen as the preferred choice of entry mode for most smallsized companies in the US. The continuing expansion of the global economy 
will almost certainly bring many more companies to that point in the future, and identifying suitable markets is generally a first step.

\section{The Export Country-Market Screening Process}

The sometimes complex realties of many foreign environments and the allure of high profit potentials require that export country-markets be sought objectively, systematically, and continuously (Cavusgil, 1985). Understanding the characteristics of available screening processes is of the utmost importance for small businesses, as they do not have the financial wherewithal to test potentially ineffective procedures (Bilkey, 1978; Ogram, 1982).

Export market screening processes were originally conceived to help companies understand information requirements as they studied the possibility of exporting to a potential pool of country-markets (Cavusgil, 1985; Kale \& Sudharshan, 1987; Root, 1982; Walvoord, 1980). The main goal of any screening process is, therefore, to reduce the number of prospective country-markets to a manageable set that can be further explored by the firm. The typical structure of a screening processes would include screening stages, screening criteria, and ranking techniques.

Most small firms would prefer to produce standardized offerings rather than to make major adjustments (or modifications) to their existing product line. This is in part due to the many potential up-front costs for such modifications, including gathering new information, laboratory testing, and patent protection, just to name a few (Terpstra, 1983; Walters, 1986). Therefore, for small firms, identifying barriers-to-exports may be more important than identifying opportunities. A screening process designed for small firms should be able to eliminate systematically those country-markets with the least likelihood of having customers who would purchase the firm's offerings as they were originally conceived for the domestic market.

Product offering selection would depend on gathering country-market information guided by company operating strategies and marketplace realities. Before undertaking any preliminary screening, managers of small businesses should have a well-rounded understanding of the firm's production expertise and capabilities (Fennell \& Saegert, 1990; Kerr \& Kirkconnell, 1989). Additionally, a firm's ability to develop cost-effective product/market research methods such as data-gathering techniques, relevant information requirements and data sources, rests on maintaining a constant vigil on what is happening in the global marketplace (Davidson, 1983).

After choosing the candidate offering, managers should review the target market profile for the product category of interest - the characteristics of the individuals (and/or organizations) that are actual or prospective customers based on their domestic marketplace experience (Davidson, 1983; Root, 1987; Terpstra, 1988). This exercise should help the company identify screening criteria based on demand-generating conditions (or circumstances) for the candi- 
date product. The next two sections discuss in more detail the screening stages and criteria, and the ranking technique characteristics.

\section{Screening Stages and Screening Criteria}

Figure 1 shows an adapted model of the screening process in export country-market selection, and screening criteria and ranking techniques in export country-market selection. The adapted model includes four screening stages: (1) country-market identification, (2) country-market market potential, (3) country-market sales potential, and (4) segment identification in the targeted country market. The screening process is very specific about the research objectives pursued at every stage. For example, the research objective of the first stage is to reduce the pool to prospective country-markets; the second stage is to reduce the pool to country-markets with higher market potential; the third stage is to select a country-market with the highest sales potential; and the fourth is to select an optimal mix of segments in the targeted country-market. In this sequential-screening approach, countries are rejected (or screened) on each new stage, (with the exception of stage 4 where segments are rejected), thus reducing the pool of countries analyzed, and consequently, the total amount of information required. However, the model assumes that, as each new stage is reached, the availability of secondary data screening criteria decreases and the need for primary data screening criteria increases, thereby increasing the quality and cost of the information required.

In the first stage, general information about countries and generic product barriers is applied to all countries. The general recommendation in this identification stage is that firms should first eliminate all country-markets that have legal, political, economic, financial, cultural and product-related barriers to exports. General country barriers include trade sanctions imposed by either the domestic or foreign governments, regulations under general or bilateral trade agreements, political risks, erratic economic behavior, cultural dissimilarities, etc. For example, until recently, the US had a total trade embargo placed on Vietnam. Therefore, Vietnam was an unlikely candidate for export activities. No US firm or subsidiary could trade with Vietnam without facing economic and/or legal sanctions (Rogers, 1994). Generic product barriers include country regulations or physical environment characteristics that might interfere with physical attributes of the product such as size, color, dimensions, and packaging. For example, Ansell Edmont, US producer of work gloves, found that Japanese workers have smaller hands and shorter fingers than their US counterparts and therefore require different gloves (Jeannet \& Hennessey, 1995, p. 337).

The advantage of this type of data is that they are readily available or observable and can be used to quickly eliminate countries. The problem with some of these indicators, however, is that they systematically vary across product categories (Green \& Kohli, 1991; Linder, 1961). In other words, the screening effectiveness of these indicators depends on the attributes possessed by the 
Figure 1

The Screening Process, Screening Criteria, and Ranking Techniques in Export Country-Market Selection

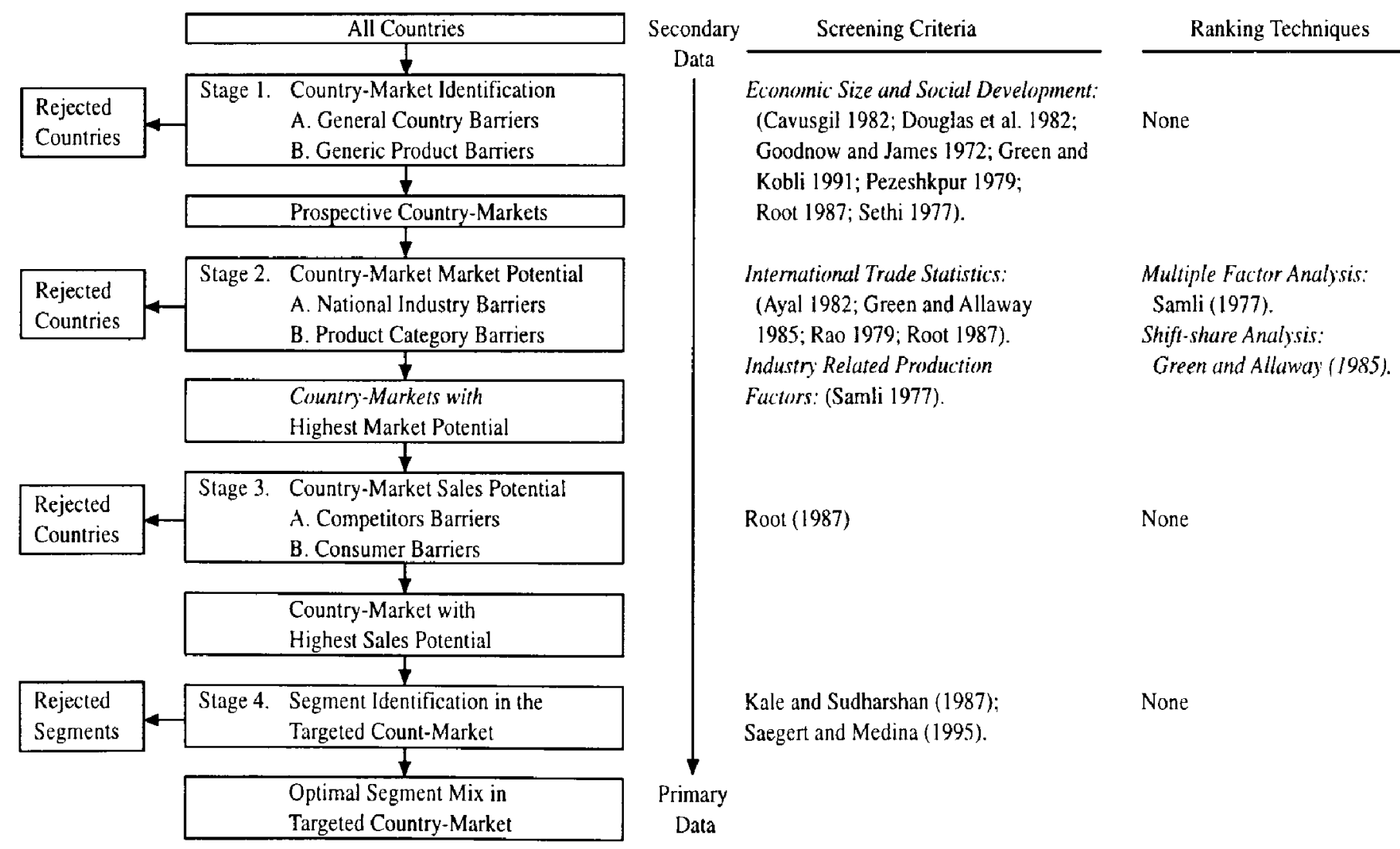


country and not on the type of product category being considered. Realistically, at this stage, countries are selected for their socioeconomic and cultural similarity to the home markets (Linder, 1961; Terpstra, 1983).

Second, to reduce the obtained pool of prospective country-markets to a set of high market potential country-markets, the national industry and product category barriers need to be analyzed. Key factors include commodity-specific trade barriers, industry entry barriers such as extent of local production, availability of local procurement, imports from third countries, negative perceptions by local consumers of the product category, and availability of product substitutes. Some of the screening criteria required at this stage are difficult to obtain for many candidate countries and products. Thus, the literature has focused on trade statistics such as flows of exports, imports and the composition of trade between countries as convenient surrogates for market potential. These indicators are becoming more important in their use because their increasing availability and reliability of measurement; and, unlike the first stage's screening criteria, they have the added advantage that they are largely a function of the product category under consideration (Green \& Kohli, 1991). Another advantage of this type of criterion over socioeconomic and political indicators such as those in stage 1 is that they account for the dynamics and the changing nature of the trade environment between economies. One possible disadvantage for small firms is that these trade statistics are usually highly aggregated. Thus they are of little help to small firms with very specific narrow product categories.

In the third stage, competitor and consumer barriers must be assessed. The strengths of direct competitors (i.e., those who sell similar brands) and their likely reaction to the small firm's entry into the industry must be assessed at this point; as well as potentially unrealistic expectations of local distributors in regards to gross margins, promotional allowances, pricing, etc. Customers' familiarity with company brand(s) and their willingness to buy them are also considered here. Potential consumers (or their representatives) of the firm's brand(s) must compare these brands with similar local brands to assess their relative advantage, their ease to use, and their compatibility with the user, just to name a few. Smaller firms are usually unaware of potential competitor's and consumer's barriers. Consequently, they are generally less confident about their knowledge regarding competitor's strengths, channels of distribution, payment conditions, etc. (Alexandrides, 1971; Ogram, 1982; Tesar \& Tarleton, 1982). However, government-sponsored export-promotion programs help small firms "test the waters" regarding brand recognition and acceptance, and comparability with local as well as international brands, by representing them in international trade fairs and shows (Czinkota \& Ricks, 1981; Barrett \& Wilkinson, 1990).

The fourth and final stage identifies segments within the country-market with the highest sales potential. Only recently has the literature addressed the importance of adding within-country-market segmentation to the screening 
process; by either following a conventional segmentation approach such as demographics, lifestyles, benefits, etc. (Kale \& Sudharshan, 1987) or by emphasizing the discovery, perhaps through focus groups, of demand-generatingcircumstance segments (Fennell \& Saegert, 1990; Saegert \& Medina, 1995). In both of these approaches, both qualitative and quantitative demand research in the candidate country-market may be required. This information, usually, can only be obtained directly from consumers in the candidate country-market and at great expense to the company. Small businesses can get some help at this stage from the US Department of Commerce's (USDOC) country-desk officers and the US Foreign Commercial Service's (USFCS) offices located in each country. These offices can direct the small company to local inexpensive private sector consultants, or they can prepare specific Country Market Plans and Comparison Shopping Surveys for moderate charges (Miller, 1993).

\section{Ranking Technique Studies}

The ranking technique is the third characteristic of the screening process. It is important not to confuse techniques used to classify country-groups on a screening criteria (Goodnow \& Hansz, 1972; Sethi, 1971) or used to define screening criteria (Green \& Kohli, 1991) with techniques used to rank country-markets on these criteria. For example, Sethi (1971) used comparative cluster analysis to agglomerate 91 countries into seven clusters along four criteria, production and transportation, personal consumption, trade, health and education. Cluster membership ranged from two to twenty eight members. Similarly, Green \& Kohli (1991) applied a multiple regression model to a data set of 102 different manufactured products to estimate the best criteria (i.e., GDP, socioeconomic development, debt burden and fuel imports) to predict imports by countries at different levels of development.

These approaches only show that countries are dissimilar (or similar) on the analyzed criteria; they are not based on some specific scale or ranking method. As far as we can tell, there are only two techniques in the literature exclusively used to rank country-markets, those of Samli (1977) and Green \& Allaway (1985). Samli's (1977) process of preliminary market selection is a multiple factor analysis technique based on the relative size and quality of potential markets. The size component is indicated by the size of the population and the quality component is indicated by the degree of economic development (as indicated by surrogate measures such as steel consumption, kilowatt hours produced, etc.) and the quality of life (as indicated by the surrogate measures such as motor vehicle registration, telephones in use, etc.) All of these variables are expressed as a percentage of the US market, which is assumed to be 100 per cent market potential. In other words, market potential for a given country is expressed in terms of the US's population, economic development, and quality of life. Country-markets are ranked based on an averaged percentage figure that present the country's potential (or market size) 
relative to other countries and compared to market size in the US. Alternatively, Green \& Allaway's (1985) study demonstrated the way in which SSA can aid in the generation of product/market sets having high export potential. After identifying products with high export potential using SSA, they again applied SSA to identify country-markets for the selected products. Next, they identified growth and a normalizing procedure to bring shifts of net share of import values to a common base. This in turn allowed them to rank countrymarkets in a scale of \pm 100 .

\section{Trade Data and Shift Share Analysis}

\section{Trade Data As Screening Criteria For Market Potential}

As indicated above, trade statistics are suggested by several authors and government reports as being good indicators of country-market market potentials (Ayal, 1982; Green \& Allaway, 1985; Plant, 1992; Rao, 1979; Root, 1987). Imports, along with market access (i.e., trade barriers, industry standards), local production, local distribution, and product category acceptability, determine market potential by prospective country-markets. Because managers are not likely to have access to all of these statistics for every prospective country, imports could be used as a representative surrogate for them all. The validity of import statistics as a surrogate lies in the fact that information from the other complementary factors is embedded in them. In other words, once trade has been consummated over a period of time, other market potential assessment criteria (i.e., industry specification standards, industry trade barriers, availability of adequate media and channels of distribution, consumers familiarity with the product category, etc.) are sufficiently reflected in import statistics. For example, if there are indications of important import activity by a country, in all probability trade barriers are manageable, there are distribution channels developed for that product category, and consumers are familiar with the product category.

The use of import statistics is even more compelling when the product category studied is in the novelty, introductory stage of its life cycle in foreign countries. In such cases, the foreign country's apparent consumption in the short run (local production plus imports minus exports) is reduced to knowing imports alone. ${ }^{1}$

Import data are, in most cases, collected and made available by the respective importing and exporting countries. Obtaining import statistics from every prospective country could be a daunting task. Therefore, US export sale statistics to the rest of the world have become a convenient and adequate substitute. Information from the US Import/Export of Merchandise reports includes data on domestic commodities (i.e., product categories) grown, produced or manufactured in the US, and commodities of foreign origin that have been changed in the US from the form in which they were imported, or that have been enhanced in value by further manufacture in the US (TRADEX 1994). 
These data are readily available on a monthly basis from the US Department of Commerce's National Trade Data Bank (NTDB).

\section{Shift Share Analysis As A Ranking Technique for Market Potential}

The main idea of shift-share analysis is to identify growth differentials (i.e., net shifts in relative share) among members of a group (e.g., countries) on a growth variable (e.g., export sales) over a period of time - beginning and end years - (Huff \& Sherr, 1967). The net shift, which is calculated in several steps (refer to Table 1 and Appendix for illustration), will be positive for products gaining market share and negative for products losing market share. Thus, group members are ranked from highest to lowest according to whether their shares have increased or decreased (Green \& Allaway, 1985; Huff \& Sherr, 1967). For example, a country that increasingly gains US-export-sales share of a product category over the years (versus other importing countries) represents a potential market for entry. This is so because the product category is clearly in the introductory or growth stage of its life cycle, and the product may be catching on and riding the crest of this cycle at a fast pace. In general, the advantages of SSA are that it requires little and simple information; it is better than either absolute or percentage growth measures; and it measures the size of share gains and losses relative to an estimated growth norm (Huff \& Sherr, 1967; Green \& Allaway, 1985).

From a country-market screening perspective, this approach, as used in the past, is subject to three important limitations. Since the traditional shift-share calculations involve only two points in time, a base year and an end year, choosing different base and end years may result in different rankings (Barff \& Knight, 1988). As most export markets do not show stability over the years, one would find it difficult to choose two "representative" points in time (Green \& Allaway, 1985). This drawback has been somewhat attenuated by the dynamic form of shift-share suggested by Barff \& Knight, (1988). In their study, these researchers calculated shift-share annually and then summed up the results over the studied period. This modification of SSA eliminates the problem of having to choose the "correct" base-year for analysis.

The second limitation of SSA to determine market potential is that it usually involves only one product category (Green \& Allaway, 1985). It does not account for the possible interactive influence of shifts in net shares of related (or complementary) product categories. For instance, there is a functional complementarity operating between the demand for printers and computers, and between the demand for golf clubs and golf balls (Solomon \& Englis, 1994). Finally, the validity of SSA as an adequate ranking technique to select countries with high market potential has not been determined. Understandably, the problem is to find alternative measures of export potential, and these are not easy to come by.

An "improved" SSA technique used for export country-market potential screening would overcome these limitations. Moreover, if the results using the 
improved technique can be supported by independent evidence, then, the identification stage (first stage in the screening model, refer to Figure 1) can be eliminated from the process, thereby adding parsimony to the overall export country-market screening process. The following section discusses the methodology used for testing an improved SSA technique.

\section{Methodology}

Mexican sauce is the novel product category selected for this study. Many new competitors are entering the Mexican sauce market in the US attracted by its incredible growth rate. Of all the producers of Mexican sauce in the US, the great majority are small or medium-sized firms with statewide or regional distribution. Only a handful of competitors are major multinational players with national and even international distribution (Packaged Facts, 1992). Although Mexican sauce and its uses are still unknown by most world consumers, there is a growing trade activity of this product between the US and other countries. SSA can help rank and identify country-markets with higher export market potential for the Mexican Sauce product category. Because Mexico and Canada are considered by many industry producers as natural extensions of the US market, these two countries are omitted from the present analysis. The tested methodology for the screening of country-markets into high market potential country-markets consisted of four steps: (1) selection of complementary products as indicators of market potential, (2) selection of time period to analyze, (3) selection of independent screening measures, and (4) shift-share analysis procedure.

\section{Selection of Complementary Products as Indicators of Market Potential.}

The domestic profile for Mexican sauce consumers guided the selection of complementary product categories that might be useful indicators of market potential. ${ }^{2}$ After carefully analyzing the information available for the domestic and foreign markets, it was discerned that the common factor on which both of these markets agreed was in the usage/circumstance. Potential foreign consumers associated Mexican sauce with snacks and dipping just as Americans do (e.g., SUSTA, 1992a \& SUSTA, 1992b). Consequently, potato and corn chips were selected as complementary products as they are related with a particular usage (i.e., dipping) and circumstance (i.e., socials) within the American context (Lawrence, 1993). The selection of these two complementary products was also based on their availability in the export trade statistics of the US.

\section{Selection of Time Period to Analyze.}

A five-year (1989-1993) period of US export sales statistics on Mexican sauce, potato chips and corn chips was examined. 1989 was chosen as the beginning year because that is the last time a commodity reclassification occurred 
Table 1

Illustration of Traditional SSA Technique Applied to US Exports of Mexican Sauces - Top 10, Middle 5, and Bottom 10 Countries

Export Data (In 000 of lbs.)

Calculation of Shift-Share Analysis

\begin{tabular}{|c|c|c|c|c|c|c|c|c|}
\hline Countries & $\begin{array}{c}1989 \\
(1) \\
\end{array}$ & $\begin{array}{c}1993 \\
(2) \\
\end{array}$ & $\begin{array}{c}\text { Actual Change } \\
(3)=(2)-(1)\end{array}$ & $\begin{array}{l}\text { Market Growth Rate } \\
(4)=(2 a) /(1 a)\end{array}$ & $\begin{array}{c}\text { Expected Value } \\
(5)=(1) \times(4)\end{array}$ & $\begin{array}{c}\text { Expected Change } \\
(6)=(5)-(1)\end{array}$ & $\begin{array}{l}\text { Net Shift } \\
(7)=(3)-(6)\end{array}$ & $\begin{array}{c}\text { Shift-Share }(\%) \\
(8)=(7) /(7 a)\end{array}$ \\
\hline 1. Netherland & 83 & 1,857 & 1774 & 1.72 & 142.76 & 59.76 & 1714.24 & $17.86 \%$ \\
\hline 2. Venezuela & 81 & 628 & 547 & 1.72 & 139.32 & 58.32 & 488.68 & $5.09 \%$ \\
\hline 3. South Korea & 46 & 466 & 420 & 1.72 & 79.12 & 33.12 & 386.88 & $4.03 \%$ \\
\hline 4. New Zealand & 94 & 531 & 437 & 1.72 & 161.68 & 67.68 & 369.32 & $3.85 \%$ \\
\hline 5. United Kingdom & 295 & 833 & 538 & 1.72 & 507.40 & 212.40 & 325.60 & $3.39 \%$ \\
\hline 6. France & 15 & 201 & 186 & 1.72 & 25.80 & 10.80 & 175.20 & $1.82 \%$ \\
\hline 7. Germany & 63 & 248 & 185 & 1.72 & 108.36 & 45.36 & 139.64 & $1.45 \%$ \\
\hline 8. Neth Antilles & 85 & 284 & 199 & 1.72 & 146.20 & 61.20 & 137.80 & $1.44 \%$ \\
\hline 9. Belgium & 4 & 112 & 108 & 1.72 & 6.88 & 2.88 & 105.12 & $1.09 \%$ \\
\hline 10. Australia & 200 & 435 & 235 & 1.72 & 344.00 & 144.00 & 91.00 & $0.95 \%$ \\
\hline 42. Slovenia & 0 & 0 & 0 & 1.72 & 0.00 & 0.00 & 0.00 & $0.00 \%$ \\
\hline 43. Haiti & 0 & 0 & 0 & 1.72 & 0.00 & 0.00 & 0.00 & $0.00 \%$ \\
\hline 44. Paraguay & 0 & 0 & 0 & 1.72 & 0.00 & 0.00 & 0.00 & $0.00 \%$ \\
\hline 45. Dominica & 0 & 0 & 0 & 1.72 & 0.00 & 0.00 & 0.00 & $0.00 \%$ \\
\hline 46. Gabon & 0 & 0 & 0 & 1.72 & 0.00 & 0.00 & 0.00 & $0.00 \%$ \\
\hline 79. United Arab E. & 135 & 38 & -97 & 1.72 & 232.20 & 97.20 & -194.20 & $-2.02 \%$ \\
\hline 80. Japan & 269 & 253 & -16 & 1.72 & 462.68 & 193.68 & -209.68 & $-2.18 \%$ \\
\hline 81. Singapore & 464 & 579 & 115 & 1.72 & 798.08 & 334.08 & -219.08 & $-2.28 \%$ \\
\hline 82. Honduras & 267 & 225 & -42 & 1.72 & 459.24 & 192.24 & $-234,24$ & $-2.44 \%$ \\
\hline 83. Spain & 165 & 27 & -138 & 1.72 & 283.80 & 118.80 & -256.80 & $-2.67 \%$ \\
\hline 84. Bahamas & 203 & 0 & -203 & 1.72 & 349.16 & 146.16 & -349.16 & $-3.64 \%$ \\
\hline 85. Costa Rica & 256 & 57 & -199 & 1.72 & 440.32 & 184.32 & -383.32 & $-3.99 \%$ \\
\hline 86. Taiwan & 962 & 1,247 & 285 & 1.72 & 1654.64 & 692.64 & -407.64 & $-4.25 \%$ \\
\hline 87. El Salvador & 316 & 100 & -216 & 1.72 & 543.52 & 227.52 & -443.52 & $-4.62 \%$ \\
\hline 88. Bermuda & 295 & 3 & -292 & 1.72 & 507.40 & 212.40 & -504.40 & $-5.25 \%$ \\
\hline All Total & $7,293(1 \mathrm{a})$ & $12,522(2 \mathrm{a})$ & 5,229 & 1.72 & $12,522.00$ & $5,229.00$ & 9600.47 & \\
\hline
\end{tabular}


for Mexican sauce. It has been through two previous reclassifications, going from broader to narrower commodity descriptions (i.e., from "tomato sauces other than ketchup," through "other sauces and preparations," to "sauces and preparations, mixed condiments and mixed seasonings.") The ending year 1993 was the latest available year for which data were available for all three products. Time series data were obtained from the United States Department of Commerce (USDOC) export trade statistics. Analyzing export statistics in unit quantity rather than dollar values is important because it eliminates possible distortions regarding changes in product prices (Gillespie \& Alden, 1989) and differences in price-quoting practices between the US and other countries. ${ }^{3}$

\section{Independent Validating Measures.}

Independent measures of country-market market potential would validate the predicted ranking of countries as estimated by SSA approaches (see Table 2). The top ten ranked country-markets having positive shift shares were matched to a composite index constituted by the combination of two ad hoc independent measures of market potential - (1) unsolicited product inquires to a southwest producer of Mexican Sauce from potential foreign clients and (2) international expansion strategies of large competitors in the US Mexican sauce industry. First, unsolicited inquires collected over a period of four years (1990-1994) by a southwest producer of Mexican sauce were tabulated by date and by country. Then, countries were ranked by their number of inquires, and the top 10 were selected. The second measure was developed based on the assumption that large domestic competitors would be actively looking for foreign expansion opportunities. An analysis of their international expansion and investment patterns would indicate where they believed to be the greatest market potential opportunities. Country-markets were ranked based on the number and type of entry strategies. ${ }^{4}$ These two validating measures of market potential were subsumed into a composite index. Countries in this index were ranked based on their number of appearances and position in the two independently obtained validating rankings.

\section{Shift-Share Analysis Procedure.}

First, traditional SSA for the years 1989 and 1993 was applied to a data set of only Mexican sauce export statistics. Then, dynamic SSA for the years 1989-1990, 1990-1991, 1991-1992, and 1992-1993 was applied to the same data set. Here SSA is calculated based on data from each year within the stated period, rather than on just "two points in time" - beginning and end years. This will help overcome the original limitation of selecting an appropriate time period and it will also increase the sensitivity of country-rankings to trade fluctuations. SSA estimates obtained for each year are arithmetically averaged giving a mean estimatc. Finally, a "modified" SSA was applied to a data set of a composite statistic of Mexican sauce, potato chips and corn chips. These three sets of top 10 ranked countries were individually compared to each of the in- 


\section{Table 2}

Top-Ten Countries From Shift Share Analysis (SSA) Ranking Approaches and Validating Measures, and Similarity Coeffecients Between SSA Ranking Approaches and Validating Index

\begin{tabular}{|c|c|c|c|c|c|}
\hline \multicolumn{3}{|c|}{ SSA Ranking Approaches } & \multicolumn{3}{|c|}{ Validating Measures } \\
\hline Traditional SSA & Dynamic SSA & Modified SSA & $\begin{array}{c}\text { Unsolicited } \\
\text { Inquiries }\end{array}$ & $\begin{array}{c}\text { Competitive } \\
\text { Analysis }\end{array}$ & $\begin{array}{c}\text { Composite } \\
\text { Index* }\end{array}$ \\
\hline 1. Netherlands & 1. Netherlands & 1. Taiwan & 1. Japan & 1. Australia & 1. Japan \\
\hline 2. Venezuela & 2. South Korea & 2. Venezuela & 2. United Kingdom & 2. Netherlands & 2. United Kingdom \\
\hline 3. South Korea & 3. New Zealand & 3. United Kingdom & 3. Venezuela & 3. Japan & 3. Australia \\
\hline 4. New Zealand & 4. Venezuela & 4. Australia & 4. South Korea & 4. United Kingdom & 4. Venezuela \\
\hline 5. United Kingdom & 5. United Kingdom & 5. Argentina & 5. Australia & 5. Venezuela & 5. Netherlands \\
\hline 6. France & 6. Neth Antilles & 6. Japan & 6. Netherlands & 6. Sweden & 6. South Korea \\
\hline 7. Germany & 7. Germany & 7. South Korea & 7. Czechoslovakia & 7. New Zealand & 7. Sweden \\
\hline 8. Neth Antilles & 8. France & 8. Peru & 8. Egypt & 8. Saudi Arabia & 8. New Zealand \\
\hline 9. Belgium & 9. Belgium & 9. Germany & 9. Ghana & 9. Kuwait & 9. Czechoslovakia \\
\hline 10. Australia & 10. Egypt & 10. Thailand & 10. Argentina & 10. South Korea & 10. Saudi Arabia \\
\hline
\end{tabular}

Similarity Coeffecients:**

$0.20 \quad 0.13 \quad 0.81$

*Composite of unsolicited inquires and competitive analysis.

**Spearman pairwise rank order correlation coefficient between the respective SSA ranking approaches and the validating composite index. 
dependently obtained validating measures using Spearman's pairwise rank-order correlation coefficient. (This coefficient helps us measure the level of similarity between these sets of data.)

\section{Findings}

The findings are presented in two sections. First, we discuss results concerning the county-market selection model in Figure 1. Then, we discuss results of applying the methodology and the SSA technique explained above.

\section{Country-market Selection Model}

Looking over Figure 1, it appears that the selection criteria need to have at least two characteristics. First, they must include a variable that is relevant in assessing the potential barriers of one country-market relative to others. Second, data on the relevant screening criterion must be available for most country-markets. Otherwise, a comprehensive and realistic comparison across countries cannot be made. The literature has emphasized studying screening criteria to identify countries in stages 1 and 2 of the model, but there is little research on screening criteria for stages 3 and 4 (see Figure 1).

Also, from our review of ranking techniques, both multiple factor analysis and SSA are potentially useful techniques for small firms as these reflect analyses from a "reference base" with a home-market framework they can understand. This reference base has commonly been the US's population, economic development, and quality of life (Samli, 1977), and the US's total exports to the rest of the world on a given product category (Green s\& Allaway, 1985). Moreover, these two techniques may actually be combined to strengthen their prediction power.

Finally, information from the adapted model in Figure 1 and from studies in the literature raise the question about the wisdom of using country-market identification techniques. The information reviewed suggests that the countrymarket identification stage can, in effect, be completely eliminated from the process for products for which information requirements at latter stages are readily available from public sources (e.g., export statistics for the market potential stage, thereby adding parsimony to the overall export country-market screening process.)

\section{SSA Technique}

Table 2 outlines the top ten ranked export country-markets from a pool of 88 countries (sec Table 1) for the three tested SSA ranking techniques traditional SSA (TSSA), dynamic SSA (DSSA), and modified SSA (MSSA) - for the two validating rankings - unsolicited inquires and competitor's analysis - and for their composite index. The table also shows the Spearman's pairwise rank order correlation coefficients for the three different types of ranking approaches and the composite index. We first discuss the 
ranking approaches and then their degree of similarity with the composite index.

The traditional and the dynamic SSA ranking approaches show "similar" country-ranking compositions as opposed to the modified SSA. This is expected as these two rankings are based on only one product category (i.e., Mexican sauce), whereas the modified SSA is based on three combined product categories (i.e., Mexican sauce, potato chips and corn chips). Also, only four countries - Venezuela, South Korea, United Kingdom, and Germany out of ten appear in all three ranking lists. Moreover, the Netherlands, Venezuela, United Kingdom, Germany, and Belgium share the same ranking in at least two of the three lists. Although the above information alone is important, as it confounds some underlying factors that influence country rankings, it does not accurately tell us anything about how good these rankings are relative to each other. By comparing visually the three ranking approaches against the validating composite index, we observe that at least half of the countries in the composite index appear on each of the three SSA estimated rankings. The traditional SSA seems to capture the most countries with a total of six, and the modified SSA seems to best capture countries with higher rankings in the composite index (i.e., Japan and Australia).

Spearman's similarity coefficients between the composite index and the three SSA ranking approaches are shown at the bottom of Table 2. These show that the modified SSA has the strongest correlation with the composite index, 0.81 . The second strongest correlation is with the traditional SSA, 0.20 , showing a slightly better association with the composite index than the dynamic SSA (0.13). This result does not support the alleged theoretical benefits obtained when in-between years are analyzed using the dynamic SSA (Barff \& Knight, 1988).

These results show that the modified SSA technique is an adequate ranking method for export country-market selection when analyzing a novel consumer packaged good. They also show that using complementary product categories does increase the power of prediction and ranking accuracy of the SSA technique.

\section{Discussion and Implications}

Small US companies selling products that are perceived as novelties in most other countries, may rely on their own domestic marketplace experience and on US-government produced export statistics to identify countries with market potential. Because the choice of foreign markets is an investment decision many small businesses are now facing, we tested the validity of a simple and inexpensive ranking method known as Shift Share Analysis (SSA) for selecting country-markets. SSA proved to be an efficient technique to rank country markets as $50 \%$ of the top-ten ranked countries were found to correspond to a composite index of two alternate validating measures. Moreover, adding 
information from complementary products to the growth variable (i.e., export sales) improves SSA predictive power significantly, suggesting that studying the small firm's own domestic market to determine possible complementary products is a worthwhile endeavor.

General assessment of market potential in a country involves an analysis of local production, local consumption, and imports and exports of the product country in question. But, information on local production, consumption and imports, and exports are usually not available when a novel product is used. In such cases, we have suggested that export sales data can be used as adequate proxy for estimating market potential. This paper demonstrates that applying US export statistics on a simple ranking technique help select countries with the highest market potential for novel packaged goods.

Although we have demonstrated empirically that US export statistics can be an adequate criterion for the screening of country-markets for a novel packaged-good product category, there are three additional theoretical reasons why US export statistics are adequate as a preliminary screen for packaged goods. First, the US is the largest exporter in the world of packaged goods (USDC, 1995). It exports most known packaged-good product categories to most countries in the world. Second, US government reports show that a significant and increasing proportion of the US's packaged goods are sought after and accepted all over the world (e.g., SUSTA, 1992a). The third reason is more practical in nature, that is, that export statistics in general are more easily available from the US government than from foreign governments.

As more trade statistics from different countries become available, small firms can benefit by applying the methodology demonstrated in this study in two ways. First, firms could lump US and foreign countries export statistics together and apply SSA. Countries with higher shares of imports, regardless of country of origin, would become prime targets for entry. Second, firms could investigate the share of US exports to importing countries relative to other exporting countries. For example, if a country has a higher share of imports from the US than it does from another country, the market potential for US products in that country will be greater. In addition, a weighting system reflecting the importance of the relative market share of exporting countries on each import market can be developed before the final country ranking exercise is done. A combination of these two approaches would perhaps be more representative of the actual level of export activity in the prospective country-markets.

A final implication from this study is that stage 1, market identification, can be omitted from our adapted country-market selection model (figure 1), when a novel product category is analyzed. Specifically, the methodology discussed in this paper can help small firms expedite the "identification of targeted areas" - an important component of any export marketing plan (Kerr \& Kirkconnell, 1989) - - for further in-depth analysis. 


\section{Future Research and Study Limitations}

It is important to remember that this study's results are primarily applicable to novel US packaged goods whose characteristics are similar to those of the Mexican sauce; namely the product must be perceived as new in most foreign markets and that there is a recent but consistent export trade history from major industry competitors in the US. However, as the product category becomes more widely distributed and produced worldwide, US export trade statistics become less attractive as a single proxy measure of market potential assessment. Also, our analysis is pertinent only to the selection of country-markets with the highest market potential (stage 2 of the model in figure 1). However, in considering a country-market's sales potential, a small firm will need to invest in the acquisition of knowledge about the specific aspects of marketing the product in each selected country. This involves obtaining data on the information requirements described in stages 3 and 4 of the model.

One limitation of using USDOC export statistics is that novel products are initially assigned to highly aggregated "catch-all' product categories, or may even be missclassified as a result of their novel nature. This in turn can affect the ranking efficacy of the SSA. One alternative to circumvent this problem, is the use of more disaggregated, and perhaps accurate, trade data from independent sources such as PIERS - Port Import Export Reporting Service - a service by the Journal of Commerce. Because PIERS reporting is based on product description and not codes, it avoids potential misclassification pitfalls that are common with newly traded products. Future studies should consider using data from this PIERS's database to test the ranking techniques developed for this study and their efficacy in selecting countries with highest market potential.

As information requirements for higher screening stages (e.g., media availability, middlemen accessibility, typical pricing policies, product packaging, etc.) become increasingly available from public sources, small businesses would benefit from empirical work that emphasizes less the determination of socioeconomic and political country criteria and more the examination of industry and product category criteria. Most export country-market selection studies found in the literature tend to group countries on socioeconomic and political barriers. There is now a growing need to go beyond this pattern of inquiry into one where we relate trade and industry barriers to specific product categories.

Finally, in regards to the ranking techniques, there is not enough breadth of options available to the small business in the literature. The only two available techniques, as described in this study, multiple factor analysis and shiftshare analysis, only apply to stage 2 in the model. Future studies should emphasize the creation of new ranking techniques applicable to this and latter stages, and the testing of their predictive validity in measuring the stage's objective (e.g., countries' market potential). 


\section{Notes}

${ }^{1}$ There is always the exceptional possibility that imports are re-exported to other countries, as is the case for many product categories in Hong Kong.

${ }^{2}$ Kotler's (1988, p. 174-175) Eight O's is a simple practical guide that profiles target markets based on eight key factors. This tool can help exporters in determining what aspects of the domestic target market resemble its foreign counterparts.

${ }^{3}$ For example, it is common for US exporters to quote CIF (Cost, insurance and freight at port of destination) or C\&F (Cost and freight at port of destination) to provide additional service to customers of certain countries. However, U.S. customs requires merchandise export sales to be estimated on a F.A.S. (free alongside ship at U.S. port of export) basis. Because individual exporters or their representatives are required to estimate this adjusted value, there is always a potential for inaccuracies in reporting that may bias export sales values for or against some countries.

${ }^{4}$ This information was obtained from articles in various food and business periodicals, general media, company annual statements, and from an interview with a marketing manager of a major manufacturer of Mexican sauce products.

\section{References}

Agarwal, Sanjjeev and Sridhar N. Ramaswami. "Choice of Country Market Entry Mode: Impact of Ownership, Location, and Internationalization Factors." Journal of International Business Studies (First Quarter, 1992): 1-27.

Alexandrides, C.G. "How the Major Obstacles to Expansion Can Be Overcome." Atlanta Economic Review 21 (1971): 12-15.

Ayal, Igal and Jehiel Zif. "Competitive Market Choice Strategies in Multinational Marketing." Columbia Journal of World Business (Fall, 1978): 72-81.

Ayal, Igal. "Industry Export Performance: Assessment and Prediction." Journal of Marketing (Fall, 1982): 72-81.

Baird, Inga S., Marjorie A. Lyles, and J. B. Orris. "Alliances and Networks: Cooperative Strategies for Small Businesses." Mid-American Journal of Business 8 (1993): 1724.

"The Choice of International Strategies by Small Businesses." Journal of Small Business Management 32 (1994): 48-59.

Barff, Richard A. and Prentice L. Knight III. "Dynamic Shift-Share Analysis." Growth \& Change 19 (1988):1-10.

Barrett, Niegel and Ian F. Wilkinson. "Australian Policies for Trade Promotion and Assistance: Review and Evaluation." In International Perspectives on Trade Promotion and Assistance, eds. S. Tamer Cavusgil and Michael R. Czinkota. New York: Quorum Books, 1990. 
Bilkey, Warren J. "An Attempted Integration of the Literature on the Export Behavior of Firms." Journal of International Business Studies (Spring/Summer, 1978): 39-55.

BusinessWeek. "It's A Small (Business) World." BusinessWeek (April 17, 1995), 96101.

Cavusgil, S. Tamer. "Guidelines for Export Market Research." Business Horizons (November/December, 1985): 27-33.

Cavusgil, S. Tamer and Shaoming Zou. "Marketing Strategy-Performance Relationship: An Investigation of the Empirical Link in Export Market Ventures." Journal of Marketing 58 (1994): 1-21.

Czinkota, Michael R. "A National Export Development Policy for New and Growing Businesses." Journal of International Marketing 2 (1994): 91-101.

Czinkota, Michael R. and David Ricks. "Export Assistance: Are We Supporting the Best Programs?" Columbia Joumal of International Business (Summer, 1981): 73-78.

Davidson, William H. "Market Similarity and Market Selection: Implications for International Marketing Strategy." Journal of Business Research 11 (1983): 439-456.

Fennell, Geraldine and Joel Saegert. "Activity v. Apriori Groups in Defining a Market." In Proceedings of the Society for Consumer Psychology, American Psychological Association Annual Conference. Boston, 1990.

Fuchs, Victor R. "Changes in the Location of US. Manufacturing Since 1929." Journal of Regional Science 1 (1959): 1-17.

Gillespie, Kate and Dana Alden. "Consumer Product Export Opportunities to Liberalizing LDCs: A Life-Cycle Approach." Journal of International Business Studies 20 (1989): 93-112.

Goodnow, James D. and James E. Hansz. "Environmental Determinants of Overseas Market Entry Strategies." Journal of International Business Studies 3 (1972): 33-50.

Green, Robert T. "Internationalization and Diversification of US Trade: 1970 to 1981." International Marketing Review (Summer, 1985): 53-62.

and Arthur W. Allaway. "Identification of Export Opportunities: A Shift-Share Approach." Journal of Marketing 49 (1985): 83-88.

and Ajay K. Kohli. "Export Market Identification: The Role of Economic Size and Socioeconomic Development." Management International Review 31 (1991): $37-50$.

and Trina L. Larsen. "Changing Patterns of U.S. Trade: 1985-1989." Business Horizons 34 (1991): 7-13. 
and Trina L. Larsen. "Japanese Trade in International Perspective." International Marketing Review 8 (1991b): 13-27.

Huff, David L. and Lawrence A. Sherr. "Measure for Determining Differential Growth Rates of Markets." Iournal of Marketing Research 4 (1967): 391-395.

Jeannet, Jean-Pierre and H. David Hennessey. Global Marketing Strategies. Boston: Houghton Mifflin Company, 1995.

Kale, Sudhir H. and D. Sudharshan. "A Strategic Approach to International Segmentation." International Market Review (Summer, 1987): 60-70.

Kerr, Jean and Paul Kirkconnell. "Export Strategies." Small Business Reports 14 (1989): 20-27.

Kotler, Philip. Marketing Management: Analysis, Planning, and Control. Englewood Cliffs, NJ: Prentice-Hall, 1988.

Lawrence, Jennifer. "Taco Bell Calls on Supermarkets." Advertising Age (February 8, 1993): 3, 47.

Linder, Staffan B. An Essay on Trade and Transformation. New York: Wiley, 1961.

McNiven, James D. "Challenge and Response: The Rise of State Export Development Policies in the U.S.A." In Export Development and Promotion: The Role of Public Organizations, eds. F. H. Rolf Seringhaus and Philip J. Rosson. New York: Klumer Academic Publishers, 1991.

Merrifield, John. "The Role of Shift-Share in Regional Analysis." Regional Science Perspectives 12 (1983): 48-53.

Miller, D. and Peter H. Friesen. "Monumentum and Revolution in Organizational Adaptation." Academy of Management Journal 23 (1980): 591-614.

Miller, Myron M. "Executive Insights: The 10-Step Road Map to Success in Foreign Markets." Journal of International Marketing 1 (1993): 89-106.

Ogram, Ernest W. "Exporters and Non-exporters: A Profile of Small Manufacturing Firms in Georgia." In Export Management: An International Context, eds. M. R. Czinkota and George Tesa. New York: Praeger, 1982.

Packaged Facts. "The Mexican Sauce Market." unpublished consultant's report on the Mexican Sauce industry (June, 1992): 31.

Plant, Mark W. "The National Trade Data Bank: The Exporter's Valuable Resource." Business America 13 (April, 1992): 16-17. 
Prosak, Sylvia Lino. "Small Businesses are Exporting." Business America 114 (November, 1993): 2-8.

Ramaswami, Sridhar N. and Yoo Yang. "Perceived Barriers to Exporting and Export Assistance Requirements." In International Perspectives on Trade Promotion and Assistance, eds. S. Tamer Cavusgil and Michael R. Czinkota. New York: Quorum Books, 1990.

Rao, C. P. "A Multilevel Approach to Researching International Markets." In International Marketing: Managerial Perspectives, eds. Subash C. Jain and Levis R. Trucker, Jr. Boston: CBI Publishing, 1979.

Rogers, John. "Firms in Place Have Advantage; Newcomers Face Uphill Climb." The Journal of Commerce (February 7, 1994): 6A.

Root, Franklin R. Entry Strategies for International Markets. Lexington, MA: D.C. Heath and Company, 1987.

Foreign Market Entry Strategies. New York: AMACOM, 1982.

Saegert, Joel and José F. Medina. "Conceptualizing Market Segmentation for the Option of Going Global." In Proceedings of the Society for Consumer Psychology, eds. Scott B. MacKenzie and Douglas M. Stayman. La Jolla, CA: American Psychological Association, 1995.

Samli, A. Coskun. "An Approach for Estimating Market Potential in East Europe." Journal of International Business Studies 8 (1977): 49-53.

Sethi, S. Prakash. "Comparative Cluster Analysis for World Markets." Journal of Marketing Research 8 (1971): 348-354.

Solomon, Michael R. and Basil G. Englis. "Observations: The Big Picture: Product Complementarity and Integrated Communications." Journal of Advertising Research (January/February, 1994): 57-63.

SUSTA - Southern United States Trade Association. "Country Profile - Hong Kong \& South Korea: Two of Asia's Tigers." Insight - Global News, Perspectives and Updates for the International Agribusiness Trade (Spring, 1992a): 3.

- "Product Profile — Snack food: Tempting Global Taste Buds." Insight - Global News, Perspectives and Updates for the International Agribusiness Trade (Spring, 1992b): 7.

Terpstra, Vern. "Critical Mass and International Marketing Strategy." Journal of the Academy of Marketing Science 11 (1983): 269-282. 
International Dimensions of Marketing. Second Edition. Boston, MA: Plus-Kent Publishing Company, 1988.

Tesar, George and Jesse S. Tarleton. "Comparison of Wisconsin and Virginia Smalland Medium-sized Exporters: Aggressive and Passive Exporters." In Export Management: An International Context, eds. M. R. Czinkota and George Tesar. New York: Praeger, 1982.

TRADEX. US Merchandise Export Trade By Commodity, United States Department of Commerce - Bureau of the Census, 1994.

USDC - United States Department of Commerce. "Statistical Abstract of the United States." The National Trade Data Book. Bureau of the Census, 1995.

Walters, Peters G. P. "International Marketing Policy: A Discussion of the Standardization Construct and Its Relevance for Corporate Policy." Journal of International Business Studies 17 (1986): 55-69.

Walvoord, Wayne R. "Export Market Research." Global Trade Magazine (May, 1980): 83.

\section{Appendix}

The shift share analysis (SSA) method has been devised to measure the relative size of the gains and losses (i.e., shift-share percentage) of market areas compared with a general market growth rate (or norm). In the present study, the market areas are individual country-markets and the norm derives from the aggregated total of these individual country-markets. The following paragraphs explain the meaning of each column and the steps to calculating shift-share percentages in Table 1 . The numbers of the formulas below, indicated in parenthesis, correspond to the same numbers in Table 1.

Countries - these are the names of the countries that constitute the individual country-markets. They are ranked from the highest to the lowest market potential.

Export Data - this is the export sales data for the beginning and end years. Let $V_{i . t}$ represent the value of the export sales for country $i$ at the end of time period $t$. Thus,

$$
V_{i, t-1} \quad \text { and }
$$

$$
V_{i, s}
$$

The total value of export sales for all the export markets from the US is equal to the sum of the values for each of the individual country markets. Thus,

$$
\prod_{\hat{A}}^{m} V_{i, r, I}
$$

Where $m$ is the number of all country-markets analyzed 
Similarly, the total value of export sales for all country-markets at the end of the terminal time period is,

$$
\begin{aligned}
& m \\
& \hat{\mathrm{A}} V_{i, t} \\
& i=l
\end{aligned}
$$

Actual Change $\left(\Delta \boldsymbol{V}_{i}\right)$ - this is the actual change of export sales in a given country, which is simply the difference in values from one time period to another. Thus,

$$
\Delta V_{i}=V_{i, r}-V_{i, r-1}
$$

Market Growth Rate $(k)$ - this is the growth rate for all country-markets, which is equal to the ratio of the total value in the terminal time period to the corresponding value in the initial time period. Thus,

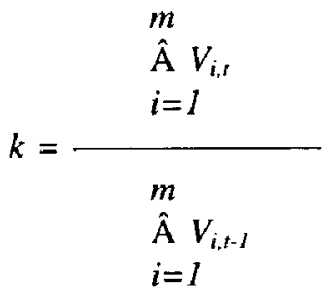

Expected Value $\left[E\left(V_{i, l}\right)\right]$ - this is the expected export sales value at the end of the terminal time period, had the country-market grown at the rate achieved for all the country-markets combined. Thus,

$$
E\left(V_{i, r}\right)=k V_{i, r-1}
$$

Expected Change $\left[E\left(\Delta V_{i}\right)\right]$ - this is the difference between the expected value and the actual value for a given country-market at the initial time period. Thus,

$$
E\left(\Delta V_{i}\right)=E\left(V_{i, t}\right)-V_{i, t-1}
$$

Net Shift $\left(\boldsymbol{N}_{i}\right)$ - this is the difference between the actual change and the expected change for a given country-market. Thus,

$$
N i=\Delta V_{i}-E\left(\Delta V_{i}\right)
$$

Absolute Net Shift (S) - The sum of the positive (or negative) net shifts. That is,

$$
\begin{aligned}
& p \\
& S=I \\
& i=I
\end{aligned}
$$

Where $p$ is the total absolute number of the positive net shifts. 
Shift-Share Percentage $\left(\boldsymbol{P}_{i}\right)-$ this is the relative gain or loss in the value of the export sales for a particular country-market during a given time period. Thus,

$$
P_{i}=\frac{N_{i}}{S}(100 \%)
$$

José F. Medina is Assistant Professor of International Marketing at the University of Texas at San Antonio. He has published papers in the Journal of International Consumer Marketing, the Journal of Consumer Affairs and the Journal of Marketing Theory and Practice, among others. His research interests include cross-cultural, export marketing and ethnic minorities research.

Joel Saegert is Professor of Marketing at the University of Texas at San Antonio. He has published papers in Psychology and Marketing, the Journal of Consumer Research, the Journal of Consumer Affairs, the Journal of Marketing, the American Journal of Psychology, the Journal of Experimental Psychology, among others. He is past-President of the Society for Consumer Psychology, Division 23 of the American Psychological Association.

John Merrifield is an Associate Professor of Economics at the University of Texas at San Antonio, a position he has held since 1987. His primary teaching and research fields include International Trade, the Environment, Natural Resource Management, Urban and Regional Economics, and Public Choice, especially K-12 School Reform. He received a B.S. in Natural Resource Management from Cal Poly San Luis Obispo in 1977, a M.A. in Economic Geography from the University of Illinois in 1979, and a Ph.D. in Economics form the University of Wyoming in 1984. 